\title{
Nurses' Knowledge about the Insertion Procedure for Peripherally Inserted Central Catheters in Newborns
}

\author{
Solange Antonia Lourenço ${ }^{1}$ \\ Conceição Vieira da Silva Ohara²
}

\begin{abstract}
The right to practice the Peripherally Inserted Central Catheter (PICC) technique, mainly in neonatal intensive care units, was achieved by nursing and consists of efforts that lead to a new challenge: the improvement of the practice of this procedure. This study determined and evaluated the theoretical and practical knowledge acquired by nurses in qualification courses concerning aspects of PICC line insertion in the case of newborns. This descriptive and quantitative study used a questionnaire with nine questions to collect data. The study population was composed of 40 nurses qualified to insert a PICC line in newborns. According to the conceptual knowledge scale established for this study, the results reveal that the nurses have inadequate knowledge concerning the studied aspects, indicating the need for nurses to constantly update and improve their knowledge about this practice so as to better the quality of care delivered to newborns.
\end{abstract}

Descriptors: Neonatal Nursing; Education, Nursing; Catheterization, Perifheral; Catheterization, Central Venous.

\footnotetext{
${ }^{1}$ RN, M.Sc. in Nursing, Pediatric Intensive Care Unit, Hospital do Coração, SP, Brazil, e-mail: sollourenco@terra.com.br.

2 Ph.D., Associate Professor, Departamento de Enfermagem, Universidade Federal de São Paulo, SP, Brazil. E-mail: consilva@ denf.epm.br.
}

Corresponding Author:

Solange Antonia Lourenço

Hospital do Coração - HCor

Rua Desembargador Eliseu Guilherme, 147

Paraíso

CEP: 04003-905 São Paulo, SP

E-mail: sollourenco@terra.com.br 


\title{
Conhecimento dos enfermeiros sobre a técnica de inserção do cateter central de inserção periférica em recém-nascidos
}

A utilização do cateter central de inserção periférica (PICC), principalmente em unidades de terapia intensiva neonatal, é uma conquista da enfermagem constituída por trajetória de esforços que conduziu a um novo desafio - o aperfeiçoamento do exercício dessa prática. Este artigo teve como objetivo verificar o conhecimento teórico-prático adquirido pelos enfermeiros, nos cursos de qualificação, sobre alguns aspectos da técnica de inserção do PICC em recém-nascidos. Trata-se de estudo descritivo, de natureza quantitativa, que utilizou como instrumento de pesquisa um questionário com nove questões. A população constituiu-se de 40 enfermeiros qualificados para inserção do PICC em neonatos. Os resultados mostraram que, segundo a atribuição conceitual estabelecida para o estudo, os enfermeiros apresentaram conhecimento ruim sobre esses aspectos, denotando a necessidade de atualização e aperfeiçoamento constante dos enfermeiros sobre essa prática para melhorar a qualidade da assistência prestada aos recém-nascidos.

Descritores: Enfermagem Neonatal; Educação em Enfermagem; Cateterismo Periférico; Cateterismo Venoso Central.

\section{Conocimiento de los enfermeros sobre la técnica de inserción del catéter central de inserción periférica en recién nacidos}

\begin{abstract}
La utilización del catéter central de inserción periférica (PICC), principalmente en unidades de terapia intensiva neonatal, es una conquista de la enfermería constituida por una trayectoria de esfuerzos que condujeron a un nuevo desafío - el perfeccionamiento del ejercicio de esa práctica. Este artículo tuvo como objetivo verificar el conocimiento teórico y práctico adquirido por los enfermeros, en los cursos de calificación, sobre algunos aspectos de la técnica de inserción del PICC en recién nacidos. Se trata de un estudio descriptivo, de naturaleza cuantitativa, que utilizó como instrumento de investigación un cuestionario con nueve preguntas. La población se constituyó de 40 enfermeros calificados para inserción del PICC en neonatos. Los resultados mostraron que, según la atribución conceptual establecida para el estudio, los enfermeros presentaron un nivel de conocimiento malo sobre esos aspectos, denotando la necesidad de actualización y perfeccionamiento constante de los enfermeros sobre esa práctica para mejorar la calidad de la asistencia prestada a los recién nacidos.
\end{abstract}

Descriptores: Enfermería Neonatal; Educación en Enfermería; Cateterismo Periférico; Cateterismo Venoso Central.

\section{Introduction}

Among the many procedures performed for newborns in Intensive Care Units (ICU), the insertion of intravascular catheters is the most frequent. The severity of a newborn's condition determines the sort of intravenous therapy, which in turn, defines the appropriate catheter to be used in the treatment ${ }^{(1-2)}$.

The central venous catheter is a very common alternative, especially in patients with hemodynamic instability. It can be performed by puncture or dissection for hemodynamic monitoring, administration of nutritional fluid, infusion of medication or hyperosmolar solutions with irritant and/or vesicant properties. The incidence of complications due to this procedure varies according to the type of catheter used, the frequency of changes, duration, and personal factors. The occurrence of bloodstream infections related to venous catheters in pediatric patients ranges from 1.7 to 2.7 infections for every 1,000 catheters/day. These complications 
aggravate newborns' clinical conditions due to the possibility of the microbiological colonization of catheters by bacteria and fungi, which may cause generalized bloodstream infections, directly increasing morbidity and mortality rates in this population ${ }^{(2-5)}$.

A device was developed in the United States in the 1970s that, when inserted into a peripheral vein and guided into the central vessels, acquires the characteristics of a central catheter. Initially implemented in ICUs, it was called Peripherally Inserted Central Catheter (PICC) Line Insertion. It is a safe alternative of central access of prolonged duration that permits the administration of solutions of high osmolarity and extreme or vesicant $\mathrm{pH}$ into the peripheral veins ${ }^{(6)}$.

This catheter has been used for about two decades in Brazil. Resolution 258/2001 of the Federal Council of Nursing (COFEN) notes in its $1^{\text {st }}$ Article that nurses are allowed to insert the PICC line but qualifies in its $2^{\text {nd }}$ article that every nurse who wishes to perform this task must attend a properly regulated qualification course ${ }^{(7)}$.

Theoretical and practical knowledge concerning the use of PICC lines is addressed in courses in neonatology and are promoted by private organizations and institutions. In general, these courses have an average workload of 24 hours and are comprised of theoretical and practical classes.

When reflecting about experiences of the use of PICC lines over the last ten years, a disturbing question emerged: Are the theoretical and practical foundations provided in courses covering PICC lines sufficient to support nurses while delivering the necessary care during this practice? Do these courses offer the necessary support for nurses to safely perform PICC line insertion?

This study verifies the theoretical and practical knowledge acquired by nurses who attended these qualifying courses examining particular aspects of PICC insertion technique such as: orientation and guidance for family members regarding the procedure, preparation of the newborn, nurse and material used in the procedure, measurement of the catheter to be inserted, preparation of the catheter, skin antisepsis and the way the catheter is inserted.

\section{Objective}

This study determined and evaluated aspects of the theoretical and practical knowledge of nurses concerning the technique involved in PICC line insertion in the case of newborns.

\section{Method}

This descriptive study was carried out in November 2006 during a scientific meeting promoted by the Group of Studies and Research in Intravenous Therapy in Pediatrics Group NECAd (Center of Child and Adolescent Studies). The study was approved by the Ethics Research Committee at UNIFESP ( $\left.n^{\circ} 0119 / 06\right)$.

The objective of this meeting was twofold: to collect data for this study and to encourage a discussion about this subject among experts in the field. Nurses experienced in the use of the PICC line gave lectures. The target audience was nurses working in intensive care units or Pediatric Intensive Care Units (PICU) and who were qualified to insert catheters in the treatment of newborns. Nurses from 26 previously selected hospitals in the city of Sao Paulo, SP, Brazil were invited by means of a folder, informing them of the meeting's program, which was sent to nursing management and/or the continuing education program of these institutions. After a search was carried out in several databases these hospitals were selected because they had one ICU or PICU or both.

A questionnaire with nine questions addressing variables related to aspects of PICC line insertion technique was used. These were based on the researcher's experience, on the literature and on course content for relevant courses. The inclusion criteria were that nurses be qualified in the technique of PICC insertion in newborns and have a minimum experience in the practice of at least one year. Sixty-five nurses attended the meeting and 32 nurses voluntarily answered the questionnaire on November $6^{\text {th }}$ after signing a free and informed consent form.

Considering that this universe of investigation is geographically concentrated and not very large, intentional sampling was used for this study based on known characteristics of a group of experts, given the researcher's knowledge about this population. The researcher can intentionally select the most varied group of respondents or select individuals typical of the population under study who have specific knowledge concerning the studied questions ${ }^{(8)}$. Therefore, the application of the questionnaire was extended for another two days in order to gather a sample of 40 respondent nurses.

Seven variables related to insertion technique were determined: orientation and guidance for family members (two questions), preparation of the newborn (one question), preparation of the nurse and material 
(one question), measurement (two questions), preparation of the catheter (one question), skin asepsis (one question) and the manner in which the catheter is inserted (one question). For measuring the variables, five options were developed and only one, according to the literature, justified the proposed variable, namely:

- orientation and guidance - two questions addressed the nurses' knowledge about the priority of obtaining the parents' or guardians' consent before initiating the procedure in view of the presented clinical case;

- preparation of the newborn - one question addressed knowledge concerning actual actions that should be performed by the nurse on the newborn before the procedure. These actions are performing a physical examination, analysis of laboratory exams and diagnostic imaging, cardiac and respiratory monitoring, restraining the newborn, analgesia and sedation.

- preparation of the nurse and material - this variable refers to the priority of actions to be performed before the insertion procedure. A single question containing the following actions was developed: hand washing, preparation of material, surgical field, nursing scrubs and preparation of the catheter;

- measurement - two questions determined the nurses' knowledge concerning the correct measurement of the catheter to be inserted in the newborn according to the insertion site's area. The first question addressed the insertion in inferior limbs' veins and the second the insertion of the catheter in superior limbs' veins;

- preparation of the catheter - this variable highlighted the proper preparation of the catheter in relation to its withdrawal, lubrication and movement of the probe or guide wire inside the catheter;

- skin asepsis -addressed the nurses' knowledge of antiseptics recommended by the Centers for Disease Control and Prevention (CDC) for skin asepsis before inserting the central catheter in newborns.;

- manner of insertion - addressed the manner of inserting the catheter, that is, slow or fast.

Data were recorded in a Microsoft Excel spreadsheet and processed by Epi-Info 3.3.2, were grouped in absolute and relative frequencies and presented in tables. A score was established according to a conceptual knowledge scale previously used in similar studies, as follows ${ }^{(9-10)}$.

Score $100 \Rightarrow$ excellent knowledge

Score from 90 to 99 points $\Rightarrow$ very good knowledge

Score from 80 to 89 points $\Rightarrow$ good knowledge

Score from 70 to 79 points $\Rightarrow$ regular knowledge
Score from 60 to 69 points $\Rightarrow$ poor knowledge

Score from 50 to 59 points $\Rightarrow$ very poor knowledge

\section{Results}

Forty nurses who graduated on average ten years before and had approximately seven years of professional experience in an ICU were investigated. Of these, $37.5 \%$ delivered direct care to patients and the remaining had more than one function in their sphere of work. In addition, $80 \%$ of the nurses had attended postgraduate programs, $93.7 \%$ of these were non-degree programs. In regard to their field of work, $59.3 \%$ worked in pediatrics and neonatology. All of them were qualified to insert a PICC line, through courses provided by three different organizations, with an average workload of 24.9 hours: 13.7 hours of theory and 11.2 of practice. The nurses had an average of three years of experience in PICC line insertion in newborns.

Table 1 - Characterization of nurses' answers concerning aspects of the technique and insertion of PICC in newborns - 2006

\begin{tabular}{|c|c|c|c|c|}
\hline \multirow{3}{*}{$\begin{array}{l}\text { Questions related to } \\
\text { variables }\end{array}$} & \multicolumn{4}{|c|}{ Answers } \\
\hline & \multicolumn{2}{|c|}{ Correct } & \multicolumn{2}{|c|}{ Incorrect } \\
\hline & $\mathbf{n}$ & $\%$ & $\mathbf{N}$ & $\%$ \\
\hline $\begin{array}{l}1 \text { - Orientation and guidance } \\
\text { (priority) }\end{array}$ & 31 & 77.5 & 9 & 22.5 \\
\hline $\begin{array}{l}2 \text { - Orientation and guidance } \\
\text { (possibility) }\end{array}$ & 37 & 92.5 & 3 & 7.5 \\
\hline $\begin{array}{l}3 \text { - Preparation of the } \\
\text { newborn }\end{array}$ & 24 & 6 & 16 & 40 \\
\hline $\begin{array}{l}4 \text { - Preparation of the nurse } \\
\text { and material }\end{array}$ & 23 & 57.5 & 17 & 42.5 \\
\hline $\begin{array}{l}5 \text { - Measurement (inferior } \\
\text { limbs' veins) }\end{array}$ & 20 & 50 & 20 & 50 \\
\hline $\begin{array}{l}6 \text { - Measurement (superior } \\
\text { limbs' veins)) }\end{array}$ & 23 & 57.5 & 17 & 42.5 \\
\hline 7 - Preparation of the catheter & 24 & 60 & 16 & 40 \\
\hline 8 - Skin asepsis & 28 & 70 & 12 & 30 \\
\hline 9 - Time of insertion & 35 & 87.5 & 5 & 12.5 \\
\hline
\end{tabular}

Table 1 shows that question nine, related to the variable about time taken to insert the PICC, obtained the largest percentage of correct answers at $87.5 \%$, which indicates that 35 nurses know the correct way of introducing the catheter well, in relation to time spent inside the blood vessel. It also shows that the variable for measurement of the catheter, when inserted in inferior limb veins (question five), obtained the lowest 
percentage of correct answers (50\%) evidencing that half the nurses do not know how to measure the correct size of the catheter to be inserted in the patient.

The second question concerning orientation and guidance for family members obtained the highest percentage of correct answers, $92.5 \%$. This question refers to the possibility of providing information to family members based on a proposed clinical case.

\section{Discussion}

The variable orientation and guidance is part of the beginning of the insertion technique and is legally required by the nurses' institutional protocol. After the medical and nursing teams determine that PICC insertion is necessary and an initial evaluation about the possibility of insertion is positive, patients and family members and legal guardians should receive orientation and guidance.

To support free choice, access to information represents patients' basic legal rights. Family members and legal guardians have the right to know options for treatment, benefits, risks and expected costs, as well as the experience and qualification of the professional responsible for the procedure. Professionals are instructed while taking courses to develop a formal and written consent form with simple language, which has to be accompanied by a nurse's verbal explanation and

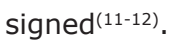

The first question covering this variable in the study reflects the knowledge that nurses have about the importance of obtaining consent before initiating the technique. The percentage of correct answers was $77.5 \%$, indicating a regular level of knowledge. The second question addressed a non-emergency clinical case in which the nurse should evaluate the appropriate point at which to instruct the family members and obtain a signed consent form. The percentage of correct answers was $92.5 \%$, that is, very good knowledge. Some studies addressing PICC line insertion revealed that only nine (5.8\%) out of 156 nurses participating in the study administered a written consent form, which is alarming(12).

The studied nurses work in ICUs and many actions are performed in this setting without family members being aware of them, that is, they are informed only after the procedure. However, nurses qualified to insert a PICC are knowledgeable about the need to provide information and use the consent form, which is an efficient work tool. The PICC line should not be inserted in emergency situations due to several risks posed. Nurses are able to provide information before the insertion. Despite nurses being legally under the jurisdiction of COFEN ${ }^{(7)}$, which is the agency that approves the PICC practice in Brazil and the consent form is not required for proceeding with PICC line insertion, according to the Brazilian law, it is up to the nurses to determine how this information will be communicated and documented. Studies suggest that providing orientation early on to mothers and children who will be submitted to invasive procedures is a useful strategy of intervention with positive implications for clinical practice ${ }^{(13)}$.

The second variable refers to preparing the newborn for the procedure. The phases of the procedure were based on the literature, studies specializing in the subject and the relevant courses' theoretical material. The phases were idealized considering needs perceived by nurses and indicated as essential to master the technique and, in addition to the gathering of information about anatomic and physiological characteristics of the newborns, this step comforts and alleviates their pain ${ }^{(11-12,14-15)}$. They are: physical examination, analysis of laboratory exams and diagnostic imaging, cardiac and respiratory monitoring, restraint, analgesia and sedation. Not performing this preparatory process might be harmful and directly interfere in the insertion sucess. Nurses working in pediatrics and all those working in the healthcare setting should always respect the rights of children established in the Statute of the Child and Adolescent according to Resolution no 41 from October 1995 of the National Council for the Rights Children and Adolescents(16). The percentage of correct answers was $60 \%$, which indicates nurses have poor knowledge of the subject.

The preparation of the nurse and material for performing PICC line insertion seeks to maintain the procedures and material sterilized according to CDC standards so as to avoid risks of systemic complications and organize and facilitate the procedure. Nurses who perform this procedure should know the importance of adhering to hospital-acquired infection prevention standards and apply them during the procedure. It is knowledge acquired not only in courses specific for this procedure, but also acquired during the education of nurses concerning insertion of central catheters. The development of these steps was based on already existent surgical procedures and CDC recommendations, adapted to this practice, namely: gathering material, aseptically preparing the surgical field, washing and brushing hands with antiseptic soap (an institutional protocol), using complete nursing scrubs (maximum barrier technique) 
and preparing the catheter. The percentage of correct answers was $57.7 \%$ indicating poor knowledge of the subject, which is cause for alarm(3,11-12,14-15).

For the variable measurement of the catheter two questions were developed. The first addressed the technique of measurement when the insertion is performed in inferior limbs' veins: initiate at the point of insertion, proceed until the inguinal region and guide it to the navel, ending at the appendix xiphoid region. The second question addresses the insertion in superior limbs' veins: initiate at the site of insertion with the arm positioned at a 90 degree angle from the thorax, proceed in the direction of the cervical region and guide it to the head of the right clavicle and then descend until the third intercostal space in the sternal line. The average percentage of correct answers for these two questions was $53.7 \%$, evidencing very poor knowledge. Nurses' lack of knowledge concerning the correct measurement of the catheter is considered a risk factor. A wrong measurement might lead to major complications such as edemas and arrhythmia, among others, and also impede the use of the catheter as a central access(11-12,14-15).

Preparing the catheter before initiating the insertion is essential. This knowledge is basically acquired in qualification courses and also from catheter suppliers. This question assessed the nurses' knowledge concerning the handling of catheters with guide wire. In general, guide wires are not used with newborns, especially with silicone catheters, due to the risk of breaking them. In a case where a guide wire is needed, the catheter is initially lubricated with a saline solution and the wire is kept inside it to facilitate its withdrawal after insertion, and the catheter is cut after measurement. Nurses displayed a $60 \%$ level of correct answers evidencing

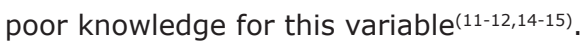

In relation to the variable skin asepsis, nurses need to know the CDC recommendations concerning the use of antisepsis solutions to insert central catheters, especially in newborns. This knowledge is acquired not only through qualification courses but also during the entire nursing education. The CDC recommends the use of antisepsis solutions on skin before inserting the catheter because skin is ruptured during the process, placing the patient at the risk of developing infections. Bacteria from the child's or the health professional's skin might colonize the insertion site area. These agents might be responsible for local infections with the potential risk of developing into a primary bloodstream infection acquired through the insertion. According to 2002 CDC recommendations (Category IA) aqueous chlorhexidine at $2 \%$, polyvinyl pyrrolidone-iodine (PVP-I) at $10 \%$, alcohol at $70 \%$ or alcohol chlorhexidine at $0.5 \%$ should be used(3,11-12,14-15). The index of correct answers was $70 \%$, considered regular.

In relation to the variable time spent to insert the catheter, we sought to assess the nurses' knowledge concerning how they should insert the catheter inside the blood vessel in relation to the time of insertion. According to the literature, the insertion should be slow, inserting 0.5 centimeters at a time in order to avoid the occurrence of mechanical phlebitis in the vessel's inner layer, which is caused by rapid insertion and consequent traction ${ }^{(11-}$ 12,14-15). The index of correct answers to this question was $87.5 \%$ evidencing nurses had good knowledge of the issue.

\section{Conclusions}

PICC line insertion demands technical expertise, clinical judgment skills and conscious, safe and efficient decision-making. This is a highly complex and specialized practice, and professionals who perform it should acquire theoretical and practical knowledge in qualification courses and incorporate knowledge from other fields previously acquired over the course of their education. The qualification courses provide nurses the basic theoretical and practical support, which enables them to safely and competently perform the procedure.

The results presented lead to the conclusion that there are many gaps between knowledge accumulated by nurses and their practice. The average percentage of the total correct answers was $67.7 \%$, which indicates that the nurses have poor knowledge in relation to PICC line insertion. Considering the characteristics of the studied population and the presented results, we verified that there is a need to continuously update and improve nurses' knowledge concerning this practice so that the construction and maintenance of this knowledge allows nurses to define guidelines for clinical practice and improve the quality of care delivered to newborns.

Graduate courses related to neonatal nursing should include programs of specific training to qualify nurses in this field of knowledge as well as resident programs in nursing, which should also incorporate this procedure as part of professional education and training.

We expect this study to help to promote the dissemination of scientific nursing knowledge in the field and support the development of this practice in the teaching field, improving qualification courses and serving as a basis of nursing actions. 


\section{References}

1. Galloway M. Using benchmarking data to determine vascular acess device selection. J Infusion Nurs 2002; 25(5):320-5.

2. Camargo PP, Kimura AF, Tsunechiro MA. Localização inicial da ponta de cateter central de inserção periférica (PICC) em recém-nascidos. Rev Latino-am Enfermagem 2008 dezembro; 42(4):723-8.

3. Centers for Disease Control and Prevention. Guideline for the Prevention of Intravascular Catheter-Related Infections. MMWR 2002; 51(RR-10): 1-29.

4. Mesiano ERAB, Merchán-Hamann E. Infecções da corrente sanguínea em pacientes em uso de cateter venoso central em unidades de terapia intensiva. Rev Latino-am Enfermagem 2007 maio-junho; 15(3):453-9.

5. Toma E. Avaliação do uso do PICC - cateter central de inserção periférica - em recém-nascidos. [tese]. São Paulo (SP): Escola de Enfermagem/USP; 2004.

6. Todd J. Clinical peripherally inserted central catheters and their use in IV therapy. Br J Nurs 1999; 8(3):140-4.

7. Conselho Federal de Enfermagem. Resolução no 258 de 12 de julho de 2001. [site na Internet] Rio de Janeiro [acesso em: 21 julho 2006]. Disponível em http://www.portalcofen.gov.br/ legislação/r258.htm.

8. Polit DF, Beck CT, Hungler BP. Fundamentos de pesquisa em enfermagem. $5^{\text {aed. }}$ Porto Alegre (RS):Artmed; 2004.

9. Archangelo AGF, Ono CM, Ribeiro DMA, Alves DT, Líbano FM. Análise do processo de vestibular da FUVEST. Adm 1998;
18:13-32.

10. Pacheco MAB. Competências mínimas do enfermeiro no pósoperatório de cirurgia cardíaca, um estudo exploratório. [tese]. Rio de janeiro(RJ): Escola de Enfermagem Anna Nery; 1981.

11. Becton Dickinson and Company. Clinical Education Manual

- Workshop of peripherally inserted central catheters in the neonate.DecisIVTM A process management approach to the relation, insertion, use, care and maitenance of extended weil catheter. Utah (EUA) Becton Dickinson; 2000.

12. Vendramim P. Cateter central de inserção periférica para acesso venoso em crianças: utilização segundo enfermeiros de hospitais do município de São Paulo.[dissertação].São Paulo (SP): Universidade Federal de São Paulo; 2004.

13. Borges LM. Treinamento de respostas de enfrentamento e colaboração de mães de crianças submetidas a procedimentos médicos invasivos.[dissertação]. Brasília (DF): Universidade de Brasília; 1999.

14. Phillips LD. Cateteres de acesso venoso central. In: Phillips LD. Manual de terapia intravenosa. $2^{a}$ ed. Porto Alegre (RS): Artmed; 2001. p. 334-64.

15. Harada MJCS, Rêgo RC. Manual de terapia intravenosa em pediatria. São Paulo (SP): Ellu; 2005.

16. Conselho Nacional dos Direitos da Criança e do Adolescente Hospitalizados. Resolução n041 de outubro de 1995. Brasil [acesso em: 05 agosto 2009]. Disponível em http://www.ufrgs. br/bioética/conanda.htm

Received: Nov. $9^{\text {th }} 2008$

Accepted: Nov. 25th 2009 